\title{
Dynamics of expression between onion line traits on the basis of phenotypic and genotypic correlations
}

\author{
V.C.V.Segundo ${ }^{1}$, C.S. de Oliveira ${ }^{2}$, R. Innecco ${ }^{1}$, J.M.Q. Luz $^{2}$, \\ J.A. de Freitas ${ }^{3}$, G.M. Maciel $^{4}$, A.P.O. Nogueira ${ }^{5}$ and A.C.S. Siquieroli ${ }^{6}$ \\ ${ }^{1}$ Departamento de Fitotecnia, Centro de Ciências Agrárias, Universidade \\ Federal do Ceará, Fortaleza, CE, Brasil \\ ${ }^{2}$ Instituto de Ciências Agrárias, Universidade Federal de Uberlândia, \\ Uberlândia, MG, Brasil \\ ${ }^{3}$ BASF Vegetable Seeds, Uberlândia, MG, Brasil \\ ${ }^{4}$ Instituto de Ciências Agrárias, Universidade Federal de Uberlândia, Monte \\ Carmelo, MG, Brasil \\ ${ }^{5}$ Instituto de Biotecnologia, Universidade Federal de Uberlândia, \\ Uberlândia, MG, Brasil \\ ${ }^{6}$ Instituto de Biotecnologia, Universidade Federal de Uberlândia, Monte \\ Carmelo, MG, Brasil \\ Corresponding author: A.C.S. Siquieroli \\ E-mail: carol@ufu.br \\ Genet. Mol. Res. 19 (3): gmr18636 \\ Received May 08, 2020 \\ Accepted August 11, 2020 \\ Published August 30, 2020 \\ DOI http://dx.doi.org/10.4238/gmr18636
}

\begin{abstract}
The cultivation of onion in Brazil has a relevant socioeconomic contribution. Despite the potential, there are few onion breeding programs for tropical conditions. One of the major obstacles is related to the complexity during the selection steps, since in onion, quantitative characters and low heritability predominate. For this reason, the purpose of this study was to assess the dynamics of expression between onion line traits based on phenotypic and genotypic correlations. Four sets of onion genotypes were assessed, comprising both advanced and segregating lines. The traits assessed were plant vigor, diameter of pseudostem, plant architecture, plant cycle, average bulb mass, bulb firmness and bulb postharvest. Phenotypic and genotypic correlations were calculated. Path analysis provided the estimate of the direct and indirect effects based on
\end{abstract}


average bulb mass as the main variable. There was dynamics in trait expression. Coherence was reported for the correlation values of the different traits among the different germplasms (experiment 1 with 109 advanced lines; experiment 2 with 227 segregating lines; experiment 3 with 53 advanced lines; and experiment 4 with 110 segregating lines). Correlations were positive for all average bulb mass $\mathrm{x}$ plant vigor experiments; plant architecture $\mathrm{x}$ plant vigor was also positive in all experiments, except for experiment 1 (109 advanced lines). The correlations which were larger in magnitude were those between bulb postharvest and plant cycle, and between bulb postharvest and average bulb mass. The phenotypic and genotypic correlations showed low association between traits in all experiments, except for experiment 3 (53 advanced lines), in which some pairs of correlations were moderate to high; however, the path analysis confirmed that the cycle (in days) and bulb postharvest showed weak cause-and-effect relationship with the main variable, rendering indirect selection impracticable for onion average bulb mass.

Key words: Allium cepa; Genotypes; Heritability; Path analysis

\section{INTRODUCTION}

Onion (Allium cepa) is a vegetable consumed and cultivated worldwide. Brazil has considerable production, which exceeds 1.5 million tons per annum (IBGE, 2017). Onion culture can be influenced by many factors, mainly photoperiod, temperature, and cultivars (Porta et al., 2014; Machado et al., 2017; Maciel et al., 2019). Additionally, climate changes, such as El Niño, La Niña, and global warming, have increased the economic and productive vulnerability of farm produce (Pereira et al., 2015). Though there are 492 records of onion cultivars in Registro Nacional de Cultivares (National Registry of Cultivars - RNC) (CultivarWeb, 2020), few are adapted to Brazilian tropical conditions.

One of the main obstacles to the development of new genotypes may be related to the traits low heritability in association with the different responses to the dynamics of behavior expression per se. Correlation studies show the direction and the degree of association between two traits. This type of information about possible association, especially between traits that pose problems for selection (due to low heritability) or for measuring and identification (Cruz et al., 2012; Teixeira et al., 2012), lead to indirect selection.

In onion breeding, bulb mass and yield are very important traits whose magnitude of heritability varies from low to high (Porta et al., 2014; Oliveira, 2015; Hussen and Albaiaty, 2019). In this regard, identifying traits correlated to bulb mass may assist the breeder with the best selection strategy, especially when heritability is low.

Despite being important, correlation coefficients only give an estimate of the magnitude and the direction of linear associations between two traits. Nonetheless, path analysis can develop the correlation coefficient into direct and indirect effects of a set of 
traits (explanatory variables) related to the expression of a main variable, the more relevant to the selection. The analysis provides accurate estimates of cause and effect (Salla et al., 2015).

In Brazil, breeding programs usually fail due to tropical conditions. One reason may be little research on the dynamics of expression between traits, especially when assessed under tropical climate. The purpose of this study was to assess the dynamics of expression between onion lines traits based on phenotypic and genotypic correlations under Brazilian conditions.

\section{MATERIAL AND METHODS}

The experiments were conducted at the Agriculture Experimental Station, in Uberlândia-MG (18 $8^{\circ} 54^{\prime} 41^{\prime \prime} \mathrm{S}, 48^{\circ} 15^{\prime} 21^{\prime \prime} \mathrm{W}$ and average altitude of 887 meters), whose soil is classified as yellow-red oxisol (Embrapa, 2006). This study assessed four experiments, two in 2016 and the other two in 2017, and a number of genotypes comprising advanced and segregating lines were analyzed (Table 1).

Table 1. Description of onion genotype groups assessed in Uberlândia-MG in 2016 and 2017.

\begin{tabular}{llll}
\hline Experiments & Number of genotypes & Year of experiment & Lines \\
\hline 1 & 109 & 2016 & Advanced* \\
2 & 227 & 2016 & Segregating** \\
3 & 53 & 2017 & Advanced \\
4 & 110 & 2017 & Segregating \\
\hline$*$ Advanced lines (lines from successive self-fertilizations). ** Segregating populations.
\end{tabular}

The genotypes were obtained from the crossing and self-fertilization of bulbs collected at trade fairs. To guarantee self-fertilization, after planting the bulbs and later sprouting, each plant was isolated inside cages at the time of its flowering, being used housefly (Musca domestica) for pollination and production of seeds. Small cages $(0.60 \mathrm{~m}$ length $\times 0.25 \mathrm{~m}$ diameter) were adopted, which covered only the umbels over the stem. Housefly pupae (2 grams per time) were added into each cage twice a week, during 40 days (main flowering time) in order to guarantee crossing and self-fertilization of plants.

The sowing for field formation in the experiments 1 and 2 (seed-to-bulb phase) was performed in March 2016, and the transplanting was done two months later. Seedbeds were plowed and fertilized according to the recommendations for growing onions (Higashikawa and Menezes Júnior, 2017). Two experiments were simultaneously conducted, one with advanced lines (109 genotypes), and the other with segregating lines (227 genotypes). The next two experiments were performed in 2017, again sowing in March and transplanting in May. The same recommendations were adopted, differing only in number and in genotypes: one experiment with advanced lines (53 genotypes), and the other with segregating lines (110 genotypes).

The experiment was arranged in a randomized block design (RBD) with two repetitions. Each plot comprised a one-meter (m) long, 0.9-m wide seedbed with five lines $0.20 \mathrm{~m}$ distant from each other, and plants were $0.05 \mathrm{~m}$ from each other (that allowed the plate of the bulb to touch the ground), totaling 100 plants per plot.

For non-metric traits, all plots were scored on a scale ranging from 1 to 9 , where 1 was the worst trait value, and 9 was the best. The agronomic traits assessed were:

Plant vigor (PV): was scored from 1 to 9 at the $90^{\text {th }}$ DAS (day after sowing), simultaneously considering leaf diameter, plant height and number of leaves; 
Diameter of the lower region of the pseudostem (DLRP): was scored from 1 to 9 at the $90^{\text {th }}$ DAS, according to the 'neck' diameter: 1 for extremely thick pseudostems, and 9 for the less thick ones (recommended);

Plant architecture (PA): was scored from 1 to 9 at the $90^{\text {th }}$ DAS, 1 for a prostrate stem, and 9 for an upright one;

Cycle (C): was the number of days from sowing to harvest. assessed:

After bulbs were harvested (average 159 days after sowing), the following traits were

Average bulb mass (ABM): ten bulbs were randomly chosen from each plot.

The following assessments were added to the 2017 experiments:

Bulb firmness (BF): five bulbs, randomly chosen from each plot, were pierced in the middle area by the $6-\mathrm{mm}$ point of a penetrometer;

Bulb postharvest $(\mathrm{BPH})$ : the percentage of marketable bulbs (suitable for consumption) after 60 days of storage under environmental conditions (average temperature of $23{ }^{\circ} \mathrm{C}$ ) was evaluated. Fifteen bulbs from each plot were assessed.

Aiming at assessing the trait dynamics in the different onion germplasms, the analyses were performed using the software $\mathrm{R}$ version 3.1.2 ( $\mathrm{R}$ Core Team, 2015). The correlation network procedure was conducted using the package "qgraph" (Epskamp et al., 2012).

Following Sneath and Sokal (1973), if multicategorical trait values can be ranked (that is, if they are ordinal numbers and can be reported on a scale), they can be treated as quantitative variables, as occurred in the present study.

The following estimators gave the phenotypic and genotypic correlations:

$$
\mathrm{rf}=\frac{\mathrm{GMPxy}}{\sqrt{\text { GMSxGMSy }}}
$$

where:

rf: phenotypic correlation estimator;

GMPxy: genotypes mean product for traits $\mathrm{X}$ and $\mathrm{Y}$;

GMSx: genotypes mean square for trait $\mathrm{X}$;

GMSy: genotypes mean square for trait Y;

$$
\mathrm{rg}=\frac{\hat{\sigma}_{\mathrm{gxy}}}{\sqrt{\hat{\sigma}_{\mathrm{gx}}^{2} \hat{\sigma}_{\mathrm{gy}}^{2}}}
$$

being:

$$
\begin{aligned}
\hat{\sigma}_{\mathrm{gxy}} & =\frac{\mathrm{GMP}_{\mathrm{xy}}-\mathrm{RMP}_{x y}}{\mathrm{r}} \\
\hat{\sigma}_{\mathrm{gx}}^{2} & =\frac{\mathrm{GMS}_{\mathrm{x}}-\mathrm{RMS}_{\mathrm{x}}}{\mathrm{r}} \\
\hat{\sigma}_{\mathrm{gy}}^{2} & =\frac{\mathrm{GMS}_{y}-\mathrm{RMS}_{y}}{\mathrm{r}}
\end{aligned}
$$

where:

rg: genotypic correlation estimator;

$\hat{\sigma}_{\text {gxy }}$ : genotypic covariance estimator between traits $\mathrm{X}$ and $\mathrm{Y}$;

RMPxy: residual mean product for traits $\mathrm{X}$ and $\mathrm{Y}$;

$\hat{\sigma}_{\mathrm{gx}}^{2}$ and $\hat{\sigma}_{\mathrm{gy}}^{2}$ : genotypic variance estimators for traits $\mathrm{X}$ and $\mathrm{Y}$, respectively;

RMSx: residual mean square for trait $X$;

RMSy: residual mean square for trait $\mathrm{Y}$; 
The significance of phenotypic correlation was estimated by $t$-test with $\mathrm{n}-2$ degrees of freedom, where $\mathrm{n}$ was the number of genotypes assessed. The significance of the genotypic correlations was assessed by bootstrap method with 5,000 simulations.

The estimate of the direct and indirect effects was given by path analysis, considering the average bulb mass as the main dependent variable. This was done only when the correlations of the main variable with other traits showed significant correlation estimates greater than or equal to 0.5 . Previously, the degree of multicollinearity was diagnosed following the criteria proposed by Montgomery et al. (2012).

The analyses were performed with the aid of the GENES software (Cruz, 2016).

\section{RESULTS AND DISCUSSION}

There was dynamics in trait expression (Figure 1). Coherence was reported within the correlation values of the different traits among the different germplasms (experiments 1, 2, 3 and 4). Correlation was positive for all ABM x PV experiments; PA x PV was also positive in all experiments, except for the 1 . The rest of the combinations did not show correlation coherence in the different experiments. The result highlighted the complexity of making gains in selection through succeeding generations of onion. Individuals or progenies selection may involve some complexity, for most of the important traits are genetic quantitative, which may present genetic epistasis and unfavorable correlations, or may be strongly influenced by environment and genotype-environment interaction (Cruz, 2006), posing difficulty for the selection process.

A
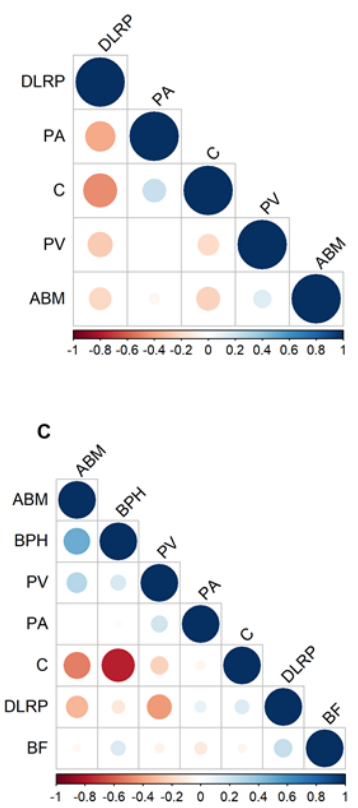

B

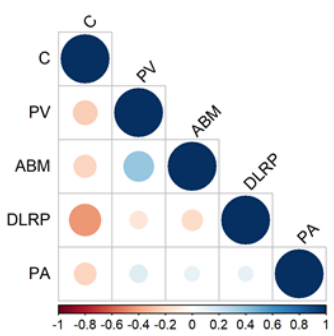

D

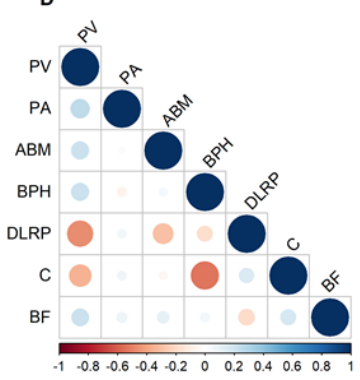

Figure 1. Dynamics of expression between traits in different onion germplasms. $\mathrm{A}=$ experiment $1 ; \mathrm{B}=$ experiment 2; $\mathrm{C}=$ experiment 3; and $\mathrm{D}=$ experiment 4. Plant vigor $(\mathrm{PV})$, diameter of the lower region of the pseudostem (DLRP), plant architecture (PA), cycle (C), average bulb mass (ABM), bulb firmness (BF) and bulb postharvest (BPH). 


\section{Experiment 1: 109 advanced lines}

Five significant phenotypic correlations by $t$-test were reported, in which the estimates ranged from 0.21 to 0.35 , showing a low degree of association between traits (Table 2).

Table 2. Phenotypic (rf) and genotypic (rg) correlation coefficients of five onion traits within 109 genotypes grown in Uberlândia-MG, 2016. Plant vigor (PV), plant architecture (PA), diameter of the lower region of the pseudostem (DLRP), cycle (C) and average bulb mass (ABM).

\begin{tabular}{|c|c|c|c|c|}
\hline Characters & $\mathbf{P A}$ & DLRP & $\mathbf{C}$ & ABM \\
\hline \multirow{2}{*}{$\mathrm{PV}$} & $\begin{array}{ll}\text { rf } & -0.03\end{array}$ & $-0.21 *$ & $-0.21 *$ & 0.15 \\
\hline & rg $\quad-0.02$ & -0.29 & -0.32 & 0.22 \\
\hline \multirow{2}{*}{ PA } & $\mathrm{rf}$ & $-0.35 * *$ & $0.21 *$ & -0.05 \\
\hline & $\mathrm{rg}$ & $-0.50+$ & 0.26 & -0.15 \\
\hline \multirow{2}{*}{ DLRP } & $\mathrm{rf}$ & & -0.47 & -0.19 \\
\hline & rg & & -0.59 & 0.09 \\
\hline \multirow[b]{2}{*}{$\mathrm{C}$} & $\mathrm{rf}$ & & & $-0.22 *$ \\
\hline & $\mathrm{rg}$ & & & $-0.36^{+}$ \\
\hline
\end{tabular}

Most genotypic correlations were higher than the phenotypic ones. In nearly all, both associations agreed as to the direction of the correlation. Thus, when the phenotypic correlation coefficient value was positive, so was the genotypic one. The same was reported for negative values. This is a very helpful insight for plant breeding programs, for it shows that the genotype expression is not masked by environment effects (Santos et al., 2015).

The significant, negative genetic correlation between plant architecture and diameter of pseudostem (-0.5) indicated that the more upright the plant was, the larger the pseudostem was. Plants in a more upright position capture more light and, therefore, have better health, which makes them more desirable.

However, plants with a very thick pseudostem diameter are undesirable, for they have greater difficulty in naturally falling over, which indicates the best time to harvest. As for plant health, they are more susceptible to diseases caused by bacteria for instance, as the water is retained in the base of the tube-shaped leaves that form the pseudostem (Menezes Júnior and Vieira Neto, 2012).

The genetic correlation between plant maturity cycle and average bulb mass was significant as well (Table 2); however, the correlation was small in magnitude, as it was below 0.7. It showed opposite direction (negative sign), for late maturity plants tend to produce small bulbs, due to the absence of the desired photoperiod when they are sowed in Uberlândia-MG (latitude $16^{\circ} \mathrm{S}$ ) in March. Evaluating the agronomic performance of 19 hybrids and 50 onion lines, Faria et al. (2012) also found a negative correlation between cycle and average bulb mass.

Despite being significant, the correlations between plant architecture and diameter of pseudostem, and between plant maturity cycle and average bulb mass were small in magnitude, raising objections to the possibility for performing indirect selection based on those traits. Since trait correlation represents the strength of a linear relationship between 
two traits (Figueiredo Filho and Silva Júnior, 2009), the above values must be handled carefully.

\section{Experiment 2: 227 segregating lines}

Seven significant phenotypic correlations by $t$-test were observed, whose estimates ranged from 0.13 to 0.39 (Table 3), revealing a low degree of association between traits.

Table 3. Phenotypic (rf) and genotypic (rg) correlation coefficients of five onion traits within 227 genotypes grown in Uberlândia-MG, 2016. Plant vigor (PV), plant architecture (PA), diameter of the lower region of the pseudostem (DLRP), cycle (C) and average bulb mass (ABM).

\begin{tabular}{|c|c|c|c|c|c|}
\hline Characters & & PA & DLRP & $\mathrm{C}$ & ABM \\
\hline \multirow{2}{*}{ PV } & $\mathrm{rf}$ & 0.10 & $-0.13^{*}$ & $-0.27 * *$ & $0.37 * *$ \\
\hline & $\mathrm{rg}$ & 0.14 & -0.11 & -0.32 & 0.52 \\
\hline \multirow{2}{*}{$\mathrm{PA}$} & $\mathrm{rf}$ & & 0.06 & $-0.18 * *$ & 0.07 \\
\hline & $\mathrm{rg}$ & & 0.09 & -0.22 & 0.14 \\
\hline \multirow{2}{*}{ DLRP } & $\mathrm{rf}$ & & & $-0.39 * *$ & $-0.19^{* *}$ \\
\hline & $\mathrm{rg}$ & & & $-0.60^{+}$ & -0.00 \\
\hline \multirow{2}{*}{$\mathrm{C}$} & $\mathrm{rf}$ & & & & $-0.21 * *$ \\
\hline & $\mathrm{rg}$ & & & & -0.35 \\
\hline
\end{tabular}

Most genotypic correlations were higher than the phenotypic ones, and the associations matched as for the direction (positive or negative). Moreover, the estimates were low, below 0.60 , which indicated a weak association between traits, according to Carvalho et al. (2004).

According to Vasconcellos et al. (1998), significance of low value correlations relates to the high degrees of freedom in $t$-test, which was corroborated by the significance between the correlation of pseudostem diameter and plant maturity cycle reported in this study. Experiment 1, with 109 lines and lower degree of freedom, showed $\mathrm{rf}=-0.47$ and $\mathrm{rg}$ $=-0.59$, both non-significant, whereas experiment 2, with 227 lines and higher degree of freedom, showed $\mathrm{rf}=-0.39^{* *}$ and $\mathrm{rg}=-0.60+$, both significant. A strategy to improve such estimates would be to increase the number of repetitions, especially if the number of treatments is limited.

The negative, significant genetic correlation between the diameter of pseudostem and plant cycle $(-0.60)$ indicated that the later the plant maturity, the thicker the pseudostem. Actually, the same was true when the photoperiod was insufficient for bulb formation. Studying the performance of onion hybrids, May et al. (2007) observed that the diameter of pseudostem increased along the cycle.

\section{Experiment 3: 53 advanced lines}

Six significant phenotypic correlations by $t$-test were observed, whose estimates ranged from 0.28 to 0.77 , revealing a low to medium degree of association (Table 4). 
Table 4. Phenotypic (rf) and genotypic (rg) correlation coefficients of six onion traits in 53 genotypes grown in Uberlândia-MG, 2017. Plant vigor (PV), diameter of the lower region of the pseudostem (DLRP), plant architecture (PA), cycle (C), average bulb mass (ABM), bulb firmness $(\mathrm{BF})$ and bulb postharvest (BPH).

\begin{tabular}{|c|c|c|c|c|c|c|}
\hline Characters & PA & DLRP & $\mathrm{C}$ & ABM & BF & BPH \\
\hline \multirow{2}{*}{ PV } & $\begin{array}{ll}\mathrm{rf} & 0.19\end{array}$ & $-0.42 * *$ & -0.22 & $0.28^{*}$ & -0.06 & 0.16 \\
\hline & rg $\quad 0.20$ & -0.41 & -0.23 & 0.25 & -0.14 & 0.22 \\
\hline \multirow{2}{*}{ PA } & $\mathrm{rf}$ & 0.09 & -0.05 & 0.00 & -0.11 & 0.02 \\
\hline & rg & 0.18 & -0.10 & -0.17 & -0.12 & 0.09 \\
\hline \multirow{2}{*}{ DLRP } & $\mathrm{rf}$ & & 0.14 & $-0.33 *$ & 0.23 & -0.12 \\
\hline & rg & & 0.16 & $-0.53^{+}$ & $0.44^{+}$ & -0.17 \\
\hline \multirow{2}{*}{$\mathrm{C}$} & $\mathrm{rf}$ & & & $-0.50 * *$ & -0.05 & $-0.77 * *$ \\
\hline & rg & & & $-0.64^{++}$ & -0.04 & $-0.85^{++}$ \\
\hline \multirow{2}{*}{$\mathrm{ABM}$} & $\mathrm{rf}$ & & & & -0.03 & $0.49 * *$ \\
\hline & rg & & & & -0.11 & $0.70^{++}$ \\
\hline \multirow{2}{*}{$\mathrm{BF}$} & $\mathrm{rf}$ & & & & & 0.15 \\
\hline & rg & & & & & 0.20 \\
\hline
\end{tabular}

For the most part, the genotypic correlations were higher than the phenotypic ones and showed the same direction, positive or negative, like the experiments of the previous year.

Studying onion genetic variability and inter-relation, Haydar et al. (2007) also reported that most of the genotypic correlation coefficients were higher than the phenotypic ones. According to the authors, the situation suggested there might be an inherent association between traits, although the environment weakened the phenotypic one. Besides, the degree of freedom contributed to the improvement of both the estimates which come from the increase in the number of repetitions and the estimates of genotypic variances and correlations.

Phenotypic correlations have both genetic and environmental causes. However, only the genetic ones are inheritable, being useful in breeding programs (Cruz et al., 2012). For this reason, they deserve special attention.

There was negative, significant genetic correlation between diameter of pseudostem and average bulb mass $(-0.53)$, between plant maturity cycle and average bulb mass $(-0.64)$, and between plant maturity cycle and bulb postharvest conservation (-0.85).

Despite being significant, the correlation between diameter of pseudostem and average bulb mass was negative and small in magnitude. Thus, a trait increased to the detriment of the other, undermining the indirect selection based on such traits. The explanation for this opposite association, previously provided for experiment 2 , showed that the average bulb mass formation was strongly influenced by photoperiod. An insufficient photoperiod caused the pseudostem to become thicker.

The significant, opposite relationship between plant maturity cycle and average bulb mass, already reported in experiment 1 , also reflected the insufficient photoperiod interference in plant maturity and bulb formation (cycle), contributing to a low average mass.

Having met the photoperiod requirement for bulb formation in a certain period (cycle), better formation and larger bulb size are expected. Therefore, it is clear that 
grouping germplasm by photoperiod requirement similarity is necessary for studies involving traits related to production, such as diameter of pseudostem, cycle and average bulb mass. In the experiments, however, many genotypes with photoperiod requirement variations were assessed, what may explain the results.

Sharma et al. (2015) assessed 21 onion genotypes and reported associations between traits related to bulb formation. Similar to our study, the authors reported significant genetic associations between bulb weight and neck thickness, and between bulb weight and the number of days until plant maturity. Differently, however, the authors reported positive correlations.

The correlation estimate between plant maturity cycle and bulb postharvest was great in magnitude, but negative, showing that earlier maturity plants had better postharvest conservation. However, part of the effect of the high, negative correlation between the two traits might be related to misshapen bulbs of some genotypes due to short photoperiod, contributing greatly to short postharvest conservation.

On the one hand, the correlations between average bulb mass and postharvest $(\mathrm{rf}=$ $0.49^{* *}$ and $\mathrm{rg}=0.70^{++}$) suggested that the heavier the bulb, the longer the postharvest conservation. On the other hand, lighter bulbs would tend to present short conservation. Nonetheless, it is worth noting that small-sized bulbs - misshapen due to insufficient photoperiod - would also tend to short conservation, as previously explained for the same correlation effects.

The study of correlations is of great relevance in terms of quantifying the magnitude and the direction of factors in trait assessment. However, the direct and indirect effects of such factors have been given little importance. Path analysis can develop the correlations into the direct and indirect effects of traits over a variable (Cruz et al., 2012).

Because average bulb mass showed significant genetic correlations higher than 0.5 with more than one variable (diameter of pseudostem, plant maturity cycle and bulb postharvest conservation), path analysis was performed to check if those traits really had a strong cause-and-effect relationship. The variables assessed by path analysis did not show issues of multicollinearity.

The low value of path coefficient of determination (0.35) and the high residual variable effect (0.80) showed weak cause-and-effect relationships between the traits assessed (Table 5).

The estimate of genotypic effects revealed that the bulb postharvest conservation produced the most direct effect on the average bulb mass (Table 5). BPH via DRLP and cycle produced little indirect effects and, therefore, was considered irrelevant to assisting with the selection process.

The direct effects showed the same sign as those of the correlations, but they were very low in magnitude (below the estimate of residual effect) for both phenotypic and genotypic effects. This means that the explanatory variables (pseudostem diameter, plant cycle and bulb postharvest conservation) were not mainly responsible for the variations of the main variable (average bulb mass), and, thus, the indirect selection would show low efficiency.

Path analysis did not supply explanation for $80 \%$ of the phenotypic variations and for $58 \%$ of the genotypic ones. This means that the path analysis provided $20 \%$ and $42 \%$ of the average bulb mass variation at phenotypic and genotypic level, respectively. 
Mohanty (2001) found different results. The author studied genetic variability, inter-relations and path analysis in onion: the number of leaves per plant (in the first place) and the neck thickness (in the second place) showed maximum direct effects on bulb formation and, therefore, were considered the most important traits in the selection.

Table 5. Estimates of phenotypic and genotypic direct and indirect effects of diameter of the lower region of the pseudostem (DLRP), cycle (C) and bulb postharvest (BPH) traits over average bulb mass (ABM) in 53 onion genotypes grown in Uberlândia, 2017.

\begin{tabular}{lll}
\hline Characters & Phenotypic effects & Genotypic effects \\
\hline Direct effects DLRP/ABM & -0.267 & -0.430 \\
Indirect effect by Cycle & -0.040 & -0.031 \\
Indirect effect by BPH & -0.029 & -0.078 \\
\hline Total & $-0.338^{*}$ & -0.539 \\
\hline Direct effects Cycle/ABM & -0.276 & -0.195 \\
Indirect effect by DLRP & -0.039 & -0.068 \\
Indirect effect by BPH & -0.189 & -0.381 \\
\hline Total & $-0.505^{* *}$ & -0.645 \\
\hline Direct effects BPH/ABM & 0.245 & 0.449 \\
Indirect effect by DLRP & 0.032 & 0.075 \\
Indirect effect by Cycle & 0.213 & 0.165 \\
\hline Total & $0.492^{* *}$ & 0.690 \\
\hline Determination coefficient & 0.350 & 0.670 \\
Residual effect & 0.800 & 0.580 \\
\hline ** and $*$ phenotypic correlation significant at the $1 \%$ and $5 \%$ level of probability by $t$-test, respectively.
\end{tabular}

Rahman et al. (2002) studied the correlation and path coefficient analyses in onion and observed that bulb diameter, bulb yield per plant and plant population were important to the total bulb yield in both analyses. The authors related the bulb individual weight gain to the large amount of space between plants.

\section{Experiment 4: 110 segregating lines}

The association between traits may be useful when one of them is hard to be selected due to low heritability or measurement issues. In this case, indirect selection based on an easily assessed, highly heritable trait is recommended. However, this trait must be highly correlated to that of difficult direct selection (Almeida at al., 2010).

Nine significant phenotypic correlations by $t$-test were reported, whose estimates ranged from -0.18 to 0.53 (Table 6), that is, they showed low degree of association. Most of the genotypic correlations were higher than the phenotypic ones and their direction matched the corresponding phenotypic associations.

This experiment, like the previous ones, showed negative association between plant vigor and diameter of pseudostem. However, significance for genetic correlation ( $\mathrm{rg}=-$ $0.63^{+}$) was observed in this experiment only.

Machado et al. (2017) studied environmental, phenotypic, and genotypic correlations in 11 onion segregating populations and observed that the genotypic correlations were higher than the phenotypic ones. The authors also found significant correlation between plant vigor and diameter of pseudostem. However, differently from the data shown here, they found a positive estimate. The fact that the present study had a 
broader scope in terms of the number of genotypes assessed might be one of the causes of the dynamics of the results. The 11 genotypes of Machado et al. (2017) study were mostly from the same group of photoperiod requirement for bulb formation. This highlighted the importance of the results of this research, whose purpose was to analyze of the dynamics of traits.

Table 6. Phenotypic (rf) and genotypic (rg) correlation coefficients of six onion traits for 110 genotypes grown in Uberlândia-MG, 2017. Plant vigor (PV), plant architecture (PA), diameter of the lower region of the pseudostem (DLRP), cycle (C), average bulb mass (ABM), bulb firmness (BF) and bulb postharvest (BPH).

\begin{tabular}{|c|c|c|c|c|c|c|c|}
\hline Characters & & PA & DLRP & $\mathrm{C}$ & ABM & BF & BPH \\
\hline \multirow{2}{*}{$\mathrm{PV}$} & $\mathrm{rf}$ & $0.25^{* *}$ & $-0.46^{* *}$ & $-0.34 * *$ & $0.21 *$ & $0.21 *$ & $0.21 *$ \\
\hline & $\mathrm{rg}$ & 0.23 & $-0.63+$ & $-0.37+$ & 0.31 & 0.32 & 0.24 \\
\hline \multirow{2}{*}{ PA } & $\mathrm{rf}$ & & 0.05 & 0.06 & 0.02 & 0.07 & -0.06 \\
\hline & $\mathrm{rg}$ & & 0.14 & 0.08 & 0.05 & 0.06 & -0.09 \\
\hline \multirow{2}{*}{ DLRP } & $\mathrm{rf}$ & & & 0.15 & $-0.29 * *$ & $-0.18^{*}$ & -0.17 \\
\hline & $\mathrm{rg}$ & & & 0.19 & $-0.53+$ & -0.40 & -0.33 \\
\hline \multirow{2}{*}{$\mathrm{C}$} & $\mathrm{rf}$ & & & & -0.04 & 0.17 & $-0.53^{* *}$ \\
\hline & $\mathrm{rg}$ & & & & 0.00 & 0.17 & $-0.63++$ \\
\hline \multirow{2}{*}{$\mathrm{ABM}$} & $\mathrm{rf}$ & & & & & 0.10 & 0.04 \\
\hline & $\mathrm{rg}$ & & & & & 0.10 & 0.11 \\
\hline \multirow{2}{*}{$\mathrm{BF}$} & $\mathrm{rf}$ & & & & & & 0.05 \\
\hline & $\mathrm{rg}$ & & & & & & 0.06 \\
\hline
\end{tabular}

The negative, significant genetic correlations between plant vigor and plant cycle ($0.37)$, between diameter of pseudostem and average bulb mass (-0.53), and between plant cycle and postharvest conservation $(-0.63)$ showed that a trait increased to the detriment of the other. The associations, however, were small in magnitude, and did not guarantee a successful indirect selection.

\section{CONCLUSIONS}

There was coherence regarding the dynamics of trait expression for the various germplasms analyzed. Overall, the phenotypic and genotypic correlations revealed low associations between the traits assessed in all experiments.

The phenotypic and genotypic correlations among plant cycle, plant architecture, average bulb mass, bulb firmness and bulb postharvest varied from low to high magnitude depending on the population origin of the evaluated genotypes.

Cycle and bulb postharvest demonstrated little direct and indirect effects on average bulb mass in 53 advanced lines and showed the impracticability of indirect selection for onion average bulb mass.

\section{ACKNOWLEDGMENTS}

The authors thank Coordenação de Aperfeiçoamento de Pessoal de Nível Superior (CAPES), Conselho Nacional de Desenvolvimento Científico e Tecnológico (CNPq), Fundação de Amparo à Pesquisa do Estado de Minas Gerais (FAPEMIG), Universidade 
Federal do Ceará (UFC) and Universidade Federal de Uberlândia (UFU) for financial support.

\title{
CONFLICTS OF INTEREST
}

\author{
The authors declare no conflict of interest.
}

\section{REFERENCES}

Almeida RD de, Peluzio JM and Aferri FS (2010). Correlações fenotípicas, genotípicas e ambientais em soja cultivada sob condições várzea irrigada, sul do Tocantins. Biosci. J. 26: 95-99.

Carvalho FIF, Lorencetti C and Benin G (2004). Estimativas e implicações da correlação no melhoramento vegetal. Editora e Gráfica Universitária UFPel, Pelotas.

Cruz CD (2006). Programa GENES: Biometria. 1st edn. Editora UFV, Viçosa.

Cruz CD, Regazzi AJ and Carneiro PCS (2012). Modelos Biométricos Aplicados ao Melhoramento Genético. 4st edn. Editora UFV, Viçosa.

Cruz CD (2016). Genes Software - extended and integrated with the R, Matlab and Selegen. Acta Sci. Agron. 38: 547552.

CultivarWeb. Ministério da Agricultura, Pecuária e Abastecimento. Available at: [http://sistemas.agricultura.gov.br/snpc/cultivarweb/cultivares registradas.php]. Accessed 23 May 2020

Embrapa. Empresa Brasileira de Pesquisa Agropecuária (2006). Sistema brasileiro de classificação de solos. 2st edn. Embrapa, Rio de Janeiro.

Epskamp S, Cramer AOJ, Waldorp LJ, Schmittmann VD, et al. (2012). qgraph: Network visualizations of relationships in psychometric data. J. Stat. Softw. 48: 1-18.

Faria MV, Morales RGF, Resende JTV, Zanin DS, et al. (2012). Desempenho agronômico e heterose de genótipos de cebola. Hortic. Bras. 30: 220-225.

Figueiredo Filho DB and Silva Júnior JA (2009). Desvendando os Mistérios do Coeficiente de Correlação de Pearson (r). Rev Polit. Hoje. 18: 115-146.

Haydar A, Sharker N, Ahmed MB, Hannan MM, et al. (2007). Genetic Variability and Interrelationship in Onion (Allium cepa L.). Middle-East J. Sci. Res. 2: 132-134.

Higashikawa FS and Menezes Júnior FOG (2017). Adubação mineral, orgânica e organomineral: efeitos na nutrição, produtividade, pós-colheita da cebola e na fertilidade do solo. Sci. Agrar. 18: 1-10.

Hussen KBEHM and Albaiaty KAH (2019). Genotypic and phenotypic variation and heritability in bulb composition of onion (Allium capa L.). Int. J. Recent Sci. Res. 10: 32345-32348.

IBGE - Instituto Brasileiro de Geografia e Estatística (2017). Levantamento Sistemático da Produção Agrícola: pesquisa mensal de previsão e acompanhamento das safras agrícolas no ano civil, IBGE, Rio de Janeiro.

Machado DLM, de Freitas JA, Luz JMQ, Maciel GM, et al. (2017). Phenotypic, genotypic and environmental correlations between characters in onion segregate populations obtained under different generations. Genet. Mol. Res. 16: gmr16039838.

Maciel GM, Marquez GR, Aguilar AS, Beloti IF, et al. (2019). Onion genotype skills in different planting systems. Cienc. Agric. 17: 35-41.

May A, Cecílio Filho AB, Porto DRQ, Vargas PF, et al. (2007). Produtividade de híbridos de cebola em função da população de plantas e da fertilização nitrogenada e potássica. Hortic. Bras. 25: 53-59.

Menezes Júnior FOG and Vieira Neto J (2012). Produção da cebola em função da densidade de plantas. Hortic. Bras. 30: 733-739.

Mohanty BK (2001). Genetic variability, inter-relationship and path analysis in onion. J. Trop Agric. 39: 17-20.

Montgomery DC, Peck EA and Vining GG (2012). Introduction to linear regression analysis. 5st edn. John Wiley \& Sons Inc, Hoboken.

Oliveira VR, Leite DL, Santos CAF and Resende GM de (2015). Botânica, melhoramento genético e cultivares de cebola. In: Cultura da cebola: tecnologias de produção e comercialização (Souza RJ de, Assis RP de, Araújo JC de, eds.). Editora UFLA, Lavras.

Pereira RM, Alves Júnior J, Casaroli D, Sales DL, et al. (2015). Viabilidade econômica da irrigação de cana-de-açúcar no cerrado brasileiro. Irriga. Edição Especial: 149-157.

Porta B, Rivas M, Gutiérrez L and Galván GA (2014). Variability, heritability, and correlations of agronomic traits in an onion landrace and derived S1 lines. Crop Breed. Appl. Biotechnol. 14: 29-35.

R Core Team (2015). R: A language and environment for statistical computing. R Foundation for Statistical Computing, Vienna, Austria. Available at:[http://www.R-project.org/]. Accessed 27 February 2020. 
Rahman MA, Saha SR, Salam MA, Masum ASMH, et al. (2002). Correlation and Path Coefficient Analysis in Onion (Allium cepa L.). J. Biol. Sci. 2: 531-532.

Salla VP, Danner MA, Citadin I, Sasso SAZ, et al. (2015). Análise de trilha em caracteres de frutos de jabuticabeira. Pesq. Agropec. Bras. 50: 218-223.

Santos A, Braga DC, Correa AM, Melo CLP de, et al. (2015). Escolha de genitores de feijão-comum baseado na divergência genética. Rev. Agrarian. 8: 235-245.

Sharma A, Sharma P and Sharma M (2015). Character association and their direct and indirect effects on bulb yield in onion. Int. J. Trop. Agric. 33: 2687-2689.

Sneath PHA and Sokal RR (1973). Numerical taxonomy: the principles and practice of numerical classification. Freeman, San Francisco.

Teixeira DHL, Oliveira MSP de, Gonçalves FMA and Nunes JAR (2012). Correlações genéticas e análise de trilha para componentes da produção de frutos de açaizeiro. Rev. Bras. Frutic. 34: 1135-1142.

Vasconcellos NJS de, Carvalho FIF de, Coimbra J, Silva SA, et al. (1998). Efeito do ambiente e correlação entre componentes do grão em genótipos de aveia cultivados no Sul do Brasil. Rev. Bras. Agrociência. 2: 85-88. 